Z a ry s treś c i. Celem artykułu jest prezentacja pojęcia pracy ze wskazaniem jej znaczenia i roli jako zasobu w wybranych nurtach nauk ekonomicznych. Rozważania podjęte w artykule mają charakter teoretyczny, zostały sformułowane w oparciu o analizę krajowej i zagranicznej literatury przedmiotu. W krajowym piśmiennictwie przedmiotu dostrzec można nieprecyzyjność w rozumieniu pracy, jej podziałów i miejsca wśród czynników produkcji. Niniejsze opracowanie prezentuje w pierwszej części historyczny rys ekonomicznych analiz pracy i jej znaczenia, jako czynnika produkcji. Druga część dotyczy problemów i nieścisłości w rozumieniu pracy i jej miejsca we współczesnych naukach ekonomicznych.

Słow a kluczowe: praca, czynniki produkcji, zasoby.

\title{
WPROWADZENIE
}

Pojęcie pracy jest w różny sposób definiowane na gruncie wielu dyscyplin nauk społecznych. Ma ona zatem interdyscyplinarny charakter. Nie podlega dyskusji stwierdzenie, że praca i jej podział pozostają w kręgu zainteresowania ludzi od zarania dziejów, a pierwsze pozytywne aspekty pracy były dostrzegane już przez starożytnych myślicieli. Współcześnie pracy ludzkiej w organizacji nadaje się coraz większe znaczenie - w relacji do jej kategoryzowania na tle innych

* Praca naukowa finansowana ze środków na naukę w latach 2010-2013 jako projekt badawczy nr N N115 327238, pt. Organizacja pracy we współczesnym przedsiębiorstwie - implikacje i uwarunkowania 
zasobów można zdecydowanie dostrzec jej dowartościowanie, wynikające z nowego podejścia do roli człowieka w procesie pracy, który jest dzisiaj nie tylko wykonawcą, ale również decydentem, na którym nie spoczywa wyłącznie odpowiedzialność za tempo pracy, ale również za sposób jej wykonania.

Celem artykułu jest prezentacja pojęcia pracy ze wskazaniem jej znaczenia i roli jako zasobu w wybranych nurtach nauk ekonomicznych. Próba realizacji celu podjęta została w oparciu o analizę krajowej i zagranicznej literatury przedmiotu.

\section{POJĘCIE ZASOBU}

Współcześnie, pojęcie zasobu ma wiele zastosowań. Oprócz ekonomii, jest ono szeroko wykorzystywane w naukach informatycznych na określenie szeregu elementów infrastruktury, zarówno twardych, jak i miękkich, które służą wykonaniu określonych operacji. Ekonomiści i specjaliści od zarządzania używają słowa „zasób” w trzech podstawowych znaczeniach.

Po pierwsze zasób (ang. stock) to sposób określania zmiennych ilościowych. W tym przypadku jest to sposób pomiaru danej wielkości ekonomicznej w danym punkcie czasu. Jest to określenie komplementarne do strumienia (ang. stream, flow), który z kolei określa daną zmienną ilościową $\mathrm{w}$ określonym przedziale czasu. Mieszkanie będące własnością konsumenta jest zasobem, posiada określoną wartość w danym czasie, dochody tego konsumenta są natomiast strumieniem, bo wyraża się je jako kwotę pieniędzy zarabianą w danym czasie.

Po drugie zasobami przedsiębiorstwa nazywane są jego czynniki produkcji ${ }^{1}$ (ang. factors of production), Wydaje się, że to sformułowanie jest lepsze do określenia wszelkich dóbr (w sensie largo), które przyczyniają się w przedsiębiorstwie do wytworzenia określonego produktu (Xu, Chaudhry, Li, 2009, s. 219).

Po trzecie, pod pojęciem zasobów (ang. resources) rozumieć można te elementy środowiska naturalnego, zarówno organiczne, jak i nieorganiczne ${ }^{2}$, które człowiek może pozyskiwać i wykorzystywać do realizacji własnych celów.

Język polski jest w tym przypadku bardzo nieprecyzyjny, przypisując temu samemu słowu trzy, tak różne znaczenia. Należy jednak stwierdzić, że wskazane określenia nie są niezwiązane. Łącząc je można stwierdzić, że czynniki produkcji mierzyć należy w danym punkcie czasu, a więc są one zasobami zgodnie z pierwszym przywołanym znaczeniem. Jednym z czynników produkcji może być natomiast pewien element pochodzący ze środowiska naturalnego.

\footnotetext{
Czynniki produkcji czasami określanie są również jako nakłady (ang. inputs).

2 Można tu dodać jeszcze jeden istotny podział zasobów naturalnych: zasoby odnawialne i zasoby nieodnawialne.
} 


\section{KLASYCZNY PODZIAŁ CZYNNIKÓW PRODUKCJI}

Dwaj przedstawiciele klasycznego nurtu w ekonomii, Adam Smith i David Ricardo rozpatrywali w swoich pracach kwestie dotyczące komponentów, które stanowią o cenach, szczególnie długookresowych ${ }^{3}$. Według nich na cenę składały się koszty wykorzystania trzech czynników ${ }^{4}$ : ziemi (ang. land), kapitału (ang. capital) i pracy (ang. labour). Pierwszy z nich to naturalnie występujące dobra, takie jak: powietrze, gleba, surowce mineralne, woda oraz fauna i flora. Drugi ze wskazanych czynników to wytworzone przez ludzi dobra, zwane również środkami produkcji - maszyny, urządzenia, budynki i budowle. Trzeci z kolei to wysiłek ludzki włożony w produkcję, zawierający również wykorzystanie fizycznych i umysłowych zdolności ludzi wykonujących pracę ${ }^{5}$ Klasyczni ekonomiści wyprowadzali ceny produktów z naturalnych stóp wynagradzania tych trzech podstawowych czynników produkcji: rent gruntowych oraz stóp zysku od kapitału i płac (Blaug, 2000, s. 300).

Klasyczni ekonomiści starali się wyprowadzić teorie wartości oparte na różnych miernikach. Najbardziej znaną i dyskutowaną ówcześnie, jak i później, jest teoria wartości oparta na pracy. Według niej, w dużym uproszczeniu, wartość danego przedmiotu jest wyrażona ilością dyskomfortu zaoszczędzonego przez jego konsumpcję lub wykorzystanie. Według Adama Smitha praca przynosi dyskomfort - jeżeli dana czynność związana jest z wysiłkiem, „dysużytecznością” czy nawet bólem, jej analiza może być istotna dla ekonomii. Adam Smith odrzucał jednak czystą teorię wartości opartą na pracy, twierdząc, że stosować ją można jedynie w prymitywnych społeczeństwach, gdzie praca człowieka należy tylko do niego. David Ricardo w przeciwieństwie do Smitha oparł wartość tylko na pracy, po części z uwagi na specyficzny charakter ówczesnych czynników produkcji: ziemia uważana była za dobro wolne, zaś „dobra kapitałowe nie były najmowane czy nabywane w kategoriach jednorodnych fizycznych jednostek"

3 Pojęcie ceny długookresowej używał dużo później Alfred Marshall, Adam Smith zaś mówił o „cenach naturalnych”, są to jednak pojęcia tożsame.

$4 \quad$ Należy jednak zwrócić uwagę, że choć każdy z nich, a także inni ekonomiści klasyczni, uznawali wyróżnienie trzech czynników produkcji, to różnili się w akcentowaniu tych, które są dla nich kluczowe.

5 Te fizyczne i umysłowe zdolności nazywane są kapitałem ludzkim. Adam Smith pisał (tłumaczenie własne): „, [Zasób społeczeństwa składa się] po czwarte z uzyskanych i użytecznych umiejętności mieszkańców lub członków społeczeństwa. Zdobycie takich talentów, poprzez utrzymywanie się przez uzyskującego podczas jego edukacji, studiów czy terminowania, zawsze kosztuje realne kwoty, co jest kapitałem stałym i zrealizowanym, do pewnego stopnia, w jego osobie. Te talenty, które są częścią jego fortuny, stanowią również to samo dla społeczeństwa, do którego on należy.” (Smith, 1904, Księga II, Rozdział 1, Paragraf 17) 
(Blaug, 2000, s. 130). Nie pozostało mu nic innego jak oprzeć się o prostą i ugruntowaną już miarę, jaką był czas pracy. Stwierdza on więc, że wartość dobra jest proporcjonalna do ilości włożonej w nią pracy, włączając $\mathrm{w}$ to pracę na wytworzenie maszyn i wydobycie surowców naturalnych ${ }^{6}$. Nie uwzględnia on, tak jak chciał Smith, sumy kwot „wypłacanych” jako wynagrodzenie wszystkich czynników użytych w produkcji. Pisał o tym wprost Jean-Baptiste Say (1855, Księga I, Rozdział X, Paragraf 6) dla ziemi - rent, dla kapitału - zysków (w uproszczeniu można mówić o odsetkach), a dla pracy - wynagrodzeń.

W ten oto sposób praca stała się dla klasyków, miernikiem wartości (Smith), a nawet idąc dalej jej źródłem (Ricardo). Sposób, w jaki analizowali oni zagadnienia związane z pracą był przełomowy i posłużył za podstawę do dalszych rozważań zarówno normatywnych jak i pozytywnych.

\section{PRACA U MARKSA}

Karol Marks w „Kapitale” rozpoczyna swoje rozważania o pracy od wskazania elementarnych czynników procesu pracy (ang. labour-process, niem. Arbeitsprozess), $\mathrm{tj}$.: pracy samej w sobie, przedmiotów pracy (obiektów przekształcanych przez pracę), instrumentów pracy (środków produkcji) (Marx, 1906, Część III, Rozdział VII, Paragraf 3). Jak widać, to ujęcie jest podobne do klasycznego, gdyż wymienione czynniki odpowiadają pracy, ziemi i kapitałowi. Marks dostrzega jednak, w przeciwieństwie do klasyków, pracę rzeczywiście wykonaną (ang. labour) od siły roboczej (ang. labour power, niem. Arbeitskraft), będącej synonimem zdolności do pracy. W tym rozróżnieniu siła robocza jest zasobem, który ma zdolność wytworzenia strumienia pracy ${ }^{7}$. Ten podział stał się podstawą krytyki kapitalizmu, gdzie siła robocza staje się towarem, a przedsiębiorca wykorzystując pracę jako czynnik produkcji może sprzedawać produkty z nadwyżką, bo wynagradza pracę poniżej wartości wytworzonych dóbr i usług. W tym rozumieniu kupowana i opłacana jest wartość wymienna siły roboczej (ang. exchange-value of labour), w rzeczywistości nabywana jest wartość użytkowa pracy (ang. use-value of labour).

6 "The value of a commodity, or the quantity of any other commodity for which it will exchange, depends on the relative quantity of labour which is necessary for its production, and not on the greater or less compensation which is paid for that labour." (Ricardo, 1821, Rozdział 1, Paragraf 1)

7 Należy również zwrócić uwagę, że $z$ dolności do pracy są zbliżone znaczeniowo do kapitału ludzkiego - Marks jednak odrzucał to porównanie, jako sposób przekonania pracownika, że jest kapitalistą. 
W rozumieniu Marksa to nie praca tworzy wartość, a siła robocza, która jest sprzedawana przedsiębiorcom przez pracowników - praca jest jedynie czynnością tworzenia wartości. W tych ramach tworzy on swoją teorię wyzysku, gdzie stwierdza, że mniejszość przedsiębiorców „oligopolizuje” środki produkcji, a pracownicy mogą przetrwać pracując wyłącznie dla „kapitalistów”.

Hipotezy Marksa miały w swoim kontekście historycznym uzasadnienie. Należy jednak stwierdzić, że w aspekcie zaprezentowanym powyżej były tylko rozwinięciem prac Smitha i Ricardo.

\section{PRACA W UJECCIU NEOKLASYCZNYM}

Pojęcie ekonomii neoklasycznej wprowadził jako pierwszy Thorstein Veblen (1900) określając nim kierunek zapoczątkowany przez Williama Jevonsa (1888), Carla Mengera (1981) i Leona Walrasa (1954), a rozwijany np. przez Alfreda Marshalla (1920) w ramach tzw. Rewolucji Marginalnej.

Neoklasykom udało się osiągnąć „wyższy stopień ogólności i oszczędności argumentacji, tłumacząc ceny zarówno czynników, jak i produktów za pomocą jednej tylko zasady" (Blaug 2000, s. 301). Nie oznacza to, że ich rozważania były lepsze od tych klasycznych. Wprowadzali oni bowiem bardziej restrykcyjne założenia, ograniczając swoje analizy do krótkiego okresu, pomijając zagadnienia związane z np. akumulacją kapitału, czy wzrostem liczby ludności (Blaug, 2000, s. 302).

Z punktu widzenia swoich analiz, marginaliści nadal stosowali klasyczny podział na trzy czynniki produkcji wprowadzony przez Smitha. Jednakże na przełomie XIX i XX wieku ekonomiści zaczęli zastanawiać się nad wyróżnieniem innych rodzajów zasobów, czy nad ograniczeniem lub zmodyfikowaniem starej ich puli ${ }^{8}$. Wspominany wcześniej Alfred Marshall zaczął rozpatrywać organizację, jako pewien rodzaj czynnika produkcji, spinający trzy klasyczne. Podobne poglądy wyrażał inny znany marginalista, John B. Clark (1908). Z kolei późniejsi ekonomiści wskazywali na przedsiębiorcę i jego pracę, jako czwarty istotny czynnik produkcji, który wynagradzany jest zyskiem (np. Wicksteed 1910). Niemniej tego typu zabiegi nie oddalają rozważań zbytnio od podstawowych trzech zasobów, zdefiniowanych w czasach klasycznych. Wracając do głównego wątku podjętego w niniejszej pracy, należy podkreślić, że Alfred Marshall dostrzegł

8 Współcześnie coraz częściej przestaje się odróżniać ziemię od kapitału, ze względu na to, że produkcyjne właściwości ziemi można często wytworzyć przy pomocy współczesnej technologii: meliorując czy użyźniając. Pierwsze tego typu koncepcje przedstawiali John B. Clark i Frank Knight, niemniej nadal jest to szeroko dyskutowane. 
i omawiał szczególne właściwości czynnika pracy (ang. peculiarities of labour) (Marshall, 1920, Księga VI, Rozdział IV):

1. pracownik sprzedaje swoją pracę, ale zachowuje kapitał „w sobie”,

2. sprzedawca pracy musi ją dostarczyć osobiście,

3. pracy nie można magazynować i oszczędzać,

4. sprzedawcy pracy są w gorszej pozycji negocjacyjnej względem jej nabywców,

5. aby dostarczyć dodatkową ilość wykwalifikowanej umiejętności potrzeba „dużo czasu” (ang. great lenght of time).

Pierwsza i druga cecha wynikają z instytucjonalnego podłoża społeczeństwa, które zabrania kupowania i sprzedawania kapitału ludzkiego. Generalnie więc dla przedsiębiorstw, jako rezerwa na wypadek nieprzewidzianych zdarzeń, kapitał ludzki jest „gorszy” od innych form kapitału. Może być jednak lepszym środkiem zabezpieczania dla pracownika, który ten kapitał akumuluje w sobie i może sam w niego inwestować. Cechy od trzeciej do piątej, o ile stanowią istotny element pracy, o tyle inne rodzaje kapitału również mogą posiadać podobne właściwości - nie jest więc to specyficzność ograniczona tylko do pracy.

Neoklasyczna ekonomia starała się opisać pracę, tak jak każdy inny czynnik produkcji: analizując jej popyt i podaż z perspektywy marginalnej. Cena pracy nie jest więc prostą funkcją marginalnej użyteczności przeciętnej osoby (czy nawet wszystkich). Wynika ona raczej z ograniczeń nakładanych przez użyteczności marginalne, przez to, że poszczególne osoby są mniej lub bardziej skłonne zawierać kontrakty.

\section{PRACA W UJĘCIU WSPÓŁCZESNYM}

Współcześnie, w teorii ekonomii poddaje się w wątpliwość paradygmat przypisujący siłę rozwoju gospodarczego wyłącznie trzem czynnikom produkcji: ziemi, kapitałowi i pracy (Perczyński, 1995, s. 328), wskazując na nowe kategorie zasobów. Od lat $90 \mathrm{XX}$ wieku zauważyć można tendencję do rozbudowywania klasycznej typologii o inne składniki. Obok trzech klasycznych zasobów pojawiają się zatem łącznie lub rozłącznie: kluczowe umiejętności (ang. competences), zasoby relacyjne (ang. relational resources), a także wiedza (ang. knowledge) lub zasoby niematerialne (ang. immaterial resources) (Hamel, 1991, s. 83-103; Dyer, Singh, 1998, s. 660-679; Grant, 2002, s. 109-122, za: Czakon, 2010, s. 9).

Zasoby relacyjne to umiejętność tworzenia relacji, które pozwalają organizacjom, na korzystanie ze specyficznych zasobów i kompetencji ich kooperantów. Inną wskazywaną współcześnie grupą zasobów są kluczowe umiejętności 
rozumiane jako niepowtarzalne organizacyjne zdolności indywidualne i grupowe leżące w umiejętności integracji i koordynacji pozostałych zasobów organizacji. (Poetivin, 1999, s. 17)

Zasób wiedzy utożsamiany jest z danymi (ujmowanym jako znaki, obrazy czy fakty), które przedstawione w odpowiednim kontekście tworzą informacje (por. Mikuła, 2005, s. 13). Kategoryzując wiedzę wskazuje się na wiedzę spersonalizowaną (jawną - komunikowalną i cichą - ukrytą) oraz wiedzę skodyfikowaną. Co istotne, przy głębszej analizie można dojść do wniosku, ze zarówno zasoby relacyjne, jak i kluczowe umiejętności stanowią wiedzę - indywidualną lub organizacyjną, a zatem kategoria zasobu wiedzy zawiera w sobie dwie pozostałe.

Idąc dalej, należy zauważyć, że wśród komponentów zasobów niematerialnych znajdują się umiejętności zarządzania oraz technologiczne, na które składają się z kolei umiejętności jednostek i grup oraz ich organizacja, a także wiedza i doświadczenie pracowników (do zasobów niematerialnych zalicza się niekiedy również nazwę przedsiębiorstwa, tradycję, markę, kontakty i jego położenie) (por. Pierścionek, 1997, s. 118), a zatem wśród grupy zasobów niematerialnych znajdują się wszystkie współcześnie „dołączone” kategorie zasobów.

Abstrahując od nieprecyzyjności w literaturze przedmiotu w ramach współczesnej typologii zasobów, należy powrócić do tematyki zasobu pracy. Poszerzona kategoryzacja zasobów w kontekście rozpatrywania pracy wydaje się niedoskonała, albowiem zasób pracy tworzą ludzie wraz z ich kapitałem. Głównym podmiotem pracy jest tu zatem człowiek - to on przy wykorzystaniu swego kapitału i przy swoim zaangażowaniu tworzy pracę. Należy zatem sprecyzować co stanowi kapitał człowieka - ujmowany w literaturze przedmiotu jako kapitał ludzki (human capital, lub w odniesieniu do jednostki individual capital). Jest on najczęściej definiowany jako zbiór właściwości tkwiących w ludziach, na które składają się wiedza, wykształcenie, umiejętności, zdolności, stan zdrowia (predyspozycje fizyczne i psychiczne), energia, motywacja do pracy, posiadające określoną wartość i które mogą być źródłem przyszłych dochodów - zarówno dla pracownika, jak i organizacji (por. Listwan, 2005, s. 57). Okazuje się zatem, że kategoryzowanie wiedzy ludzi w ramach odrębnego zasobu lub subkategoryzowanie w grupie zasobów niematerialnych (wraz z umiejętnościami i doświadczeniem pracowników) powoduje dublowanie używania tych samych pojęć w ramach różnych grup zasobów, tj. w ramach zasobu pracy i w ramach zasobu wiedzy i/lub zasobów niematerialnych. Można wprawdzie spodziewać się, w odniesieniu do powyższych wywodów, zarzutów dotyczących wąskiego ujęcia wiedzy - tu sprowadzonej poniekąd do wiedzy spersonalizowanej. Przyglądając się jednak głębiej przedstawionemu problemowi należy dostrzec, że wiedza kategoryzowana jako skodyfikowana ma charakter zbywalny, a zatem mieści się w ramach kategorii zasobu, którym jest kapitał. Warto zatem w tym miejscu przywołać po 
raz drugi kwestię kwot „wypłacanych” jako wynagrodzenie wszystkich zasobów: dla ziemi - rent, dla kapitału - zysków, a dla pracy - płac. Praca, którą wykonuje człowiek dzięki swoim umiejętnościom, zdolnościom, doświadczeniu i wiedzy jest wynagradzana płacą, natomiast wiedza skodyfikowana np. w postaci receptur czy baz danych może być odsprzedana konkurentowi i będzie stanowić zysk przedsiębiorstwa. Analogicznie można przeanalizować pozostałe składniki kategorii zasobów niematerialnych.

Reasumując, należy dojść do wniosku, że klasyczny podział zasobów na trzy grupy: ziemię, pracę i kapitał wydaje się najbardziej trafny. Należy równolegle zauważyć, iż w ramach tej podstawowej typologii, na przestrzeni lat, dokonało się przewartościowanie znaczenia poszczególnych grup zasobów. Ziemia była dominującym zasobem w czasach gospodarki agrarnej, kapitał - epoki przemysłowej, w epoce informacyjnej zaś szczególnego znaczenia nabiera praca, ze względu na kapitał, którym dysponują ludzie. W czasach gospodarki agrarnej i przemysłowej, charakteryzujących się prostym i rutynowym wykonywaniem czynności roboczych, zasób pracy wynagradzany był przez pryzmat wydajności. W obecnych czasach, gdy materialne czynniki produkcji stają się do siebie coraz bardziej podobne, powtarzalne i łatwo dostępne, to praca i jej unikalność stanowią główne źródło przewagi konkurencyjnej. Kwalifikacje industrialnych pracowników zastąpione zostały przez maszyny, zatem współczesne przedsiębiorstwa poszukują wykonawców pracy charakteryzujących się wysokimi kwalifikacjami, unikalnymi umiejętnościami i wiedzą. Praca we współczesnym przedsiębiorstwie polega bowiem na wychodzeniu poza rutynowo wykonywane zadania oraz na umiejętnym wykorzystywaniu i dzieleniu się wiedzą. W literaturze w odniesieniu do takiego wykonywania pracy używa się sformułowań pracownik ekspert lub pracownik wiedzy $\mathrm{w}$ odniesieniu do pracownika o unikalnych kompetencjach, żywym umyśle, perfekcji w działaniu, który dąży do mistrzostwa zawodowego (Morawski, 2005, s. 205).

\section{ZAKOŃCZENIE}

Rozważania podjęte w artykule nie wyczerpują możliwości różnorodnego postrzegania i kategoryzacji pracy. W świetle dokonanej analizy literatury przedmiotu, może budzić wątpliwości współczesna - szeroka kategoryzacja zasobów, która powoduje wielokrotne powielanie tych samych pojęć w ramach różnych grup czynników produkcji. Nie zmienia to jednak kwestii przewartościowania znaczenia pracy, która aktualnie odgrywa dominującą rolę, jako źródło przewagi konkurencyjnej współczesnej organizacji. Reasumując, wydaje się, że rezultaty przeprowadzonej analizy mogą stanowić punkt wyjścia do podjęcia dyskusji w zakresie systematyki pojęcia czynników produkcji i ich komponentów. 


\section{LITERATURA}

Blaug, M. (2000), Teoria ekonomii. Ujęcie Retrospektywne. Wydawnictwo Naukowe PWN, Warszawa.

Clark, J. B. (1908), The Distribution of Wealth: A Theory of Wages, Interest and Profits. New York: The Macmillan Company. Library of Economics and Liberty dostępne z http://www.econlib.org/library/Clark/clkDW.html; pobrane 7 lutego 2011.

Czakon W. (2010), Zasobowa teoria firmy w krzywym zwierciadle, Przegląd Organizacji, $\mathrm{nr} 4$.

Dyer J., Singh H. (1998), The Relational View: Corporative Strategy and Sources of Interorganizational Competitive Advantage, Academy of Management Review, vol. 24, no.4.

Grant R. (2002), Towards a Knowledge Based Teory of the Firm, Strategic Management Journal, vol. 17.

Hamel G. (1991), Competition for Competence and Interpartner Learning within International Strategic Alliances, Strategic Management Journal, vol. 12.

Jevons, W. S. (1888), The Theory of Political Economy. London: Macmillan and Co., Library of Economics and Liberty, dostępne z http://www.econlib.org/library/ YPDBooks/Jevons/jvnPE.html; pobrane 7 lutego 2011.

Listwan T. red., (2005), Stownik Zarządzania Kadrami, C.H. Beck, Warszawa.

Marshall, A. (1920). Principles of Economics. Macmillan and Co., Ltd., Londyn. Library of Economics and Liberty, dostępne z http://www.econlib.org/library/Marshall/ marP46.html; pobrano 7 lutego 2011.

Marx, K. (1906), Capital: A Critique of Political Economy, Vol. I. The Process of Capitalist Production. Charles H. Kerr and Co., Chicago, Library of Economics and Liberty, dostępne z http://www.econlib.org/library/YPDBooks/Marx/mrxCpA7. html; pobrano 7 lutego 2011.

Menger, C. (1981), Principles of Economics, New York University Press, Nowy Jork.

Mikuła B. (2005), Wiedza jako przedmiot zarzadzania, [w:] Perechuda K. (red.), Zarządzanie wiedza w przedsiębiorstwie, PWN, Warszawa.

Morawski M. (2005), Zarządzanie pracownikami wiedzy, [w:] Perechuda K. (red.), Zarzadzanie wiedza w przedsiębiorstwie, PWN, Warszawa.

Perczyński M. (1995), Globalizacja i nacjonalizm wobec współczesnych wyzwań rozwojowych, Ekonomista, nr 1-2.

Pierścionek Z. (1997), Strategie rozwoju firmy, PWN, Warszawa.

Poetivin M. (1999), Fondements et analyses, Les Presses de L'Universite Laval, Saint-Nicolas.

Ricardo, D. (1821). On the Principles of Political Economy and Taxation. John Murray. Londyn, Library of Economics and Liberty, dostępne z http://www.econlib.org/library/Ricardo/ricP1.html; pobrano 7 lutego 2011.

Say, J-B. (1855), A Treatise on Political Economy. Lippincott, Grambo \& Co., Philadelphia, Library of Economics and Liberty dostępne $\mathrm{z}$ http://www.econlib.org/ library/Say/sayT10.html; pobrane 7 lutego 2011. 
Smith, A (1904), An Inquiry into the Nature and Causes of the Wealth of Nations. Methuen \& Co., Ltd., Londyn, Library of Economics and Liberty, dostępne z http://www.econlib.org/library/Smith/smWN6.html; pobrano 7 lutego 2011.

Veblen, T. (1900). „The Preconceptions of Economic Science - III”, The Quarterly Journal of Economics, 14 (2), s. 240-269.

Walras, L. (1954), Elements of Pure Economics, Allen and Unwin, Londyn 1954.

Wicksteed, P. H. (1910), The Common Sense of Political Economy. Macmillan and Co., Londyn, Library of Economics and Liberty, dostępne z http://www.econlib.org/ library/Wicksteed/wkCS9.html; pobrano 7 lutego 2011.

Xu, B., Chaudhry, S. S. Li, Y. (2009), „Factors of production: Historical theories and new developments", Systems Research and Behavioral Science, $\mathrm{nr} 26$.

\section{LABOUR AS FACTOR OF PRODUCTION - THE CONCEPT OF LABOUR AND ITS SIGNIFICANCE IN ECONOMICS}

A b s tract. The main goal of this paper is to present the significance of the term labour, and to point out its role as a factor of production in chosen schools of economics. The studies conducted in the paper have purely theoretical scope and had been undertaken based on the analysis of Polish and foreign literature. In Polish writings, one can notice some inaccuracy in understanding labour, its divisions and place among factors of production. In the first part of this paper the reader can find historical overview of economic analysis of labour and its significance as a factor of production. Second part concerns problems and impreciseness in studies over labour and its place in economics.

K e y w ords : labour, resources, factors of production 